\title{
Is pore water oxygen content decoupled from productivity on the California Margin? Trace element results from Ocean Drilling Program Hole 1017E, San Lucia slope, California
}

\author{
I. L. Hendy \\ Department of Geological Sciences, University of Michigan, Ann Arbor, Michigan, USA
}

\author{
T. F. Pedersen \\ School of Earth and Ocean Sciences, University of Victoria, Victoria, British Columbia, Canada \\ Received 2 December 2004; revised 13 April 2005; accepted 7 September 2005; published 20 December 2005.
}

[1] Trace element evidence from the California Margin (Ocean Drilling Program Hole 1017E) shows significant changes in sediment redox chemistry at intermediate water depths over the last $60 \mathrm{kyr}$. The influence of export production on intermediate water oxygen content can be distinguished from lateral ventilation through comparisons among proxies representing export production flux (percent $\mathrm{C}_{\text {org }}$ ) and sediment-surface $(\mathrm{I} / \mathrm{Br})$ and pore water (Mo, Ag, Cd, Re, and U) oxygenation proxies. Sulfate reduction within the uppermost sediment column occurred during late Quaternary interstadials and the Holocene, indicating reduced intermediate water ventilation. However, sulfate reduction was most intense during major interstadials when productivity was enhanced. Decoupling between export production and pore water oxygen content is demonstrated during deglaciation when the sediment pore water oxygen content increases without a corresponding reduction in export productivity. Thus both export production and intermediate water ventilation play a role in oxygen minimum zone processes on the California Margin.

Citation: Hendy, I. L., and T. F. Pedersen (2005), Is pore water oxygen content decoupled from productivity on the California Margin? Trace element results from Ocean Drilling Program Hole 1017E, San Lucia slope, California, Paleoceanography, 20, PA4026, doi:10.1029/2004PA001123.

\section{Introduction}

[2] The well-defined oxygen minimum zone (OMZ) is a significant feature along the California Margin at present. However, during the last glacial period, large changes in pore water oxygen content have been inferred from geochemical and micropaleontological records suggesting that the OMZ waxed and waned in close concert with rapid climate change in the North Atlantic [Cannariato and Kennett, 1999; van Geen et al., 1996; Zheng et al., 2000b]. Two primary influences control pore water oxygen concentrations along the margin: the settling flux of organic carbon, which is closely related to upwelling intensity and primary production, and the dissolved oxygen concentration of the intermediate waters that bathe the local seafloor. At present there is no consensus on the relative importance of these two processes in controlling the strength of the OMZ along the North American Margin.

[3] Ocean Drilling Program Hole 1017E $\left(34^{\prime} 32^{\prime \prime}{ }^{\circ} \mathrm{N}\right.$, $121^{\prime} 6^{\prime \prime} \mathrm{W}$; $955 \mathrm{~m}$ water depth) is located near the base of the OMZ some $60 \mathrm{~km}$ to the west of Point Conception, southern California (Figure 1). A high settling flux of organic matter is supported by a persistent upwelling cell that overlies the site and supplies nutrients to the surface

Copyright 2005 by the American Geophysical Union. 0883-8305/05/2004PA001123 waters [Hendy et al., 2004]. Bottom waters bathing the site reflect two sources: relatively well oxygenated North Pacific Intermediate Waters (NPIW) originating in the NW Pacific and poorly oxygenated waters advected north by the California Undercurrent from the eastern tropical Pacific. ODP Site 1017 is ideally located to monitor the temporal interplay of export production and intermediate water circulation through the application of a variety of proxies that correspond to each of these major influences. Trace and minor element composition can provide information on changes in bottom water oxygen levels [Calvert and Pedersen, 1993] and the sedimentary redox boundary depth [Crusius et al., 1996], while variability in the deposition of specific biogenic components relates to the history of upwelling, export productivity, and intermediate water renewal. Combining of these proxies allows for the separation of intermediate water ventilation history from the decay of organic material related to export production when interpreting the history of the oxygen minimum zone.

[4] The proximity of Site 1017 to Santa Barbara basin ( $\sim 70 \mathrm{~km} \mathrm{SE})$ presents an opportunity to test the hypothesis that bottom water oxygenation of Santa Barbara Basin has been driven by changes in intermediate water source strength and/or character in the North Pacific [Cannariato and Kennett, 1999; Crusius et al., 2004; Kennett and Ingram, 1995]. This contrasts with the hypothesis put forward by Ortiz et al. [2004] whose explanation for 


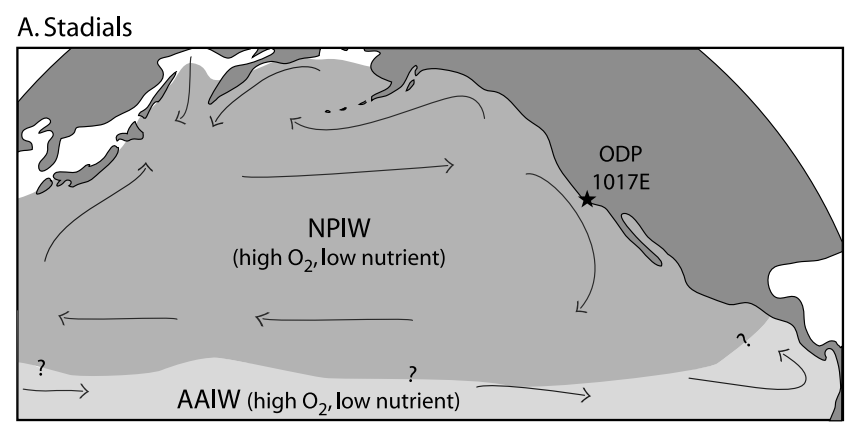

B. Interstadials

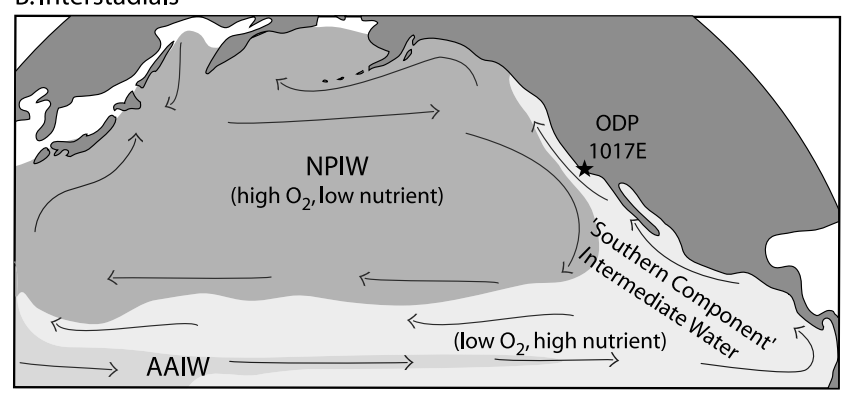

Figure 1. Maps of (a) intermediate water circulation during stadial events and (b) intermediate water circulation during interstadial events of the last glacial [Hendy and Kennett, 2003; Hendy et al., 2004]. NPIW is North Pacific Intermediate Water; AAIW is Antarctic Intermediate Water.

changes in OMZ strength involve the decay of organic matter resulting from export production controlled by coastal upwelling.

\subsection{Upwelling Processes}

[5] Under persistent northerly winds, water off Point Conception wells up from approximately $300 \mathrm{~m}$ water depth in the core of the California Undercurrent flow. The undercurrent originates in the eastern tropical Pacific, and flows as far north as Vancouver Island $\left(\sim 50^{\circ} \mathrm{N}\right)$ with the northernmost extent of its influence controlled by the position of the West Wind Drift [Hickey, 1979; Reid, 1965]. The California Undercurrent is 10 to $40 \mathrm{~km}$ wide physically confined to the continental slope and has significant seasonal variability in flow. The current is characteristically warm, saline, phosphate-rich, and oxygen-poor [Hickey, 1979]. The mid depth of the current off Point Conception is $200-300 \mathrm{~m}$, but it can be deeper than $500 \mathrm{~m}$ during spring [Hickey, 1979]. Its flow speed is generally slow $(<10 \mathrm{~cm} / \mathrm{s})$, but occasionally exceeds $22 \mathrm{~cm} / \mathrm{s}$ [Noble and Ramp, 2000].

\subsection{Intermediate Water Circulation}

[6] The influence of NPIW on the California Margin at the depth of the OMZ today and possible intensification of NPIW during the last glacial episode has been widely discussed [Cannariato and Kennett, 1999; Crusius et al., 2004; Gardner et al., 1997; Kennett and Ingram, 1995; Lund and Mix, 1998; van Geen et al., 1996]. NPIW is defined as the subsurface salinity minimum centered on the $26.80 \sigma$ density surface [Talley, 1991]. Ventilation of this water mass occurs both in the Bering Sea [Takahashi, 1998] and the Sea of Okhotsk [Talley, 1991] through sea ice formation and vertical mixing, as well as in the Alaskan Gyre where shoaling of NPIW occurs close to the base of the mixed layer [Van Scoy et al., 1991b]. Geostrophic flow along this density surface is generally equatorward except in the eastern Pacific where the flow turns westward at $20^{\circ} \mathrm{N}$, leaving a large area of the eastern tropical Pacific not directly renewed by intermediate water that formed in the north (Figure 1) [Reid, 1965].

[7] A well-ventilated water mass has been inferred to exist at intermediate water depths $(<2000 \mathrm{~m})$ in the far northwestern Pacific during the last glaciation [Keigwin, 1998]. Through the same interval changes of bottom water oxygen concentration in association with millennial-scale climatic cycles have been recognized in Santa Barbara Basin [Behl and Kennett, 1996; Kennett and Ingram, 1995]. These variations were attributed to the reduced influence of northward flowing southern-component intermediate water (modified AAIW) [Hendy and Kennett, 2003] commensurate with intensification of NPIW formation in the high latitude North Pacific (Figure 1) [Keigwin, 1998]. Thus the intermediate water circulation cell in the North Pacific intensified and expanded during the coolest interval of the last glacial episode [Keigwin, 1998] and further California Undercurrent flow waxed and waned in association with Dansgaard-Oeschger cycles [Hendy and Kennett, 2003].

\section{Methods}

[8] Concentrations of I and $\mathrm{Br}$ were determined for 337 samples from 5.9 to $15.4 \mathrm{~m}$ subbottom depth using a Phillips PW 24000 X-ray spectrometer equipped with a Rh tube run at $3 \mathrm{~kW}$, following the method of [Calvert, 1984]. The concentration of $\mathrm{Br}$ was corrected for the diluting effect of sea salt in the dried samples using titrimetric chlorinity determinations [Strickland and Parsons, 1972] on distilled water leachates of $50 \mathrm{mg}$ samples. Concentrations of Re, U, $\mathrm{Mo}, \mathrm{Ag}$ and $\mathrm{Cd}$ were determined for 532 samples from 0 to $15.4 \mathrm{~m}$ by isotope dilution on a VG Plasmaquad II+ ICP-MS in the peak-jumping mode. Prior to analysis, spiked sediment samples were subjected to total dissolution by microwave digestion in a $\mathrm{HCl}, \mathrm{HNO}_{3}, \mathrm{HF}$ acid cocktail in Teflon test tubes following [Crusius et al., 1996]. The ${ }^{95} \mathrm{Mo}:{ }^{98} \mathrm{Mo}$, ${ }^{185} \mathrm{Re}:{ }^{187} \mathrm{Re},{ }^{238} \mathrm{U}:{ }^{233} \mathrm{U},{ }^{109} \mathrm{Ag}:{ }^{107} \mathrm{Ag}$ and ${ }^{111} \mathrm{Cd}:{ }^{113} \mathrm{Cd}$ ratio spikes were calibrated using standard solutions made from high-purity standards.

[9] Trace metal concentrations are not normalized to titanium or aluminium in this contribution as elemental concentrations of $\mathrm{Ti}$ and $\mathrm{Al}$ are more influenced by grain size in this nearshore environments than terrigenous contribution [Irino and Pedersen, 2000; Tada et al., 2000]. That increases in trace metal concentration represent enrichment is demonstrated by their high concentrations in sediments. As well when normalized to either $\mathrm{Ti}$ or $\mathrm{Al}$, the profiles remain unchanged. The chronology presented in this contribution differs from that presented by Kennett et al. [2000] and is discussed in greater detail by Hendy et al. [2004]. It is assumed in this age model that interstadials 
(IS) 5 to 17 are synchronous with interstadial events recorded in the Greenland ice cores.

\section{Results}

[10] The sediment redox chemistry at ODP Site 1017 can be organized into three diagenetic environments [Berner, 1980]: Oxic environments are defined as those in which the pore waters contain measurable dissolved oxygen and diagenesis occurs via aerobic metabolism. After $\sim 90 \%$ of the dissolved oxygen concentration is consumed through organic matter decomposition, secondary oxidants (primarily nitrate, manganese and iron oxides) are depleted in the suboxic zone and the sediments become progressively more reducing. Little measurable dissolved sulfide is present in this zone [Berner, 1980]. Where oxidant demand remains sufficiently high, sulfate reduction occurs in the underlying anoxic zone leading to the buildup of high dissolved $\mathrm{HS}^{-}$ concentrations.

\subsection{Oxic Indicators: Sedimentary Iodine-Bromine Ratios}

[11] Iodine and bromine concentrations in marine sediments are fundamentally controlled by bottom water oxygen content, organic matter content of the deposits, and postdepositional reactions related to organic matter degradation [Price and Calvert, 1977]. Where surface sediments are oxic (bottom water is oxygenated), the concentrations of both elements track the organic matter content closely. Under suboxic and anoxic conditions, however, I in surface sediments is typically depleted relative to $\mathrm{Br}$ [Shimmield and Pedersen, 1990, and references therein]. This contrast stems from the differing geochemistry of the two halogens.

[12] The bromide ion $\left(\mathrm{Br}^{-}\right)$is the principal $\mathrm{Br}$ species in seawater irrespective of the redox potential, while I exists in two primary species whose distributions are highly sensitive to the redox potential (Eh). The iodate ion $\left(\mathrm{IO}^{3-}\right)$ dominates under oxic conditions, but in suboxic and anoxic settings, $\mathrm{IO}^{3-}$ is quantitatively reduced to iodide at close to the Eh of nitrate reduction [Wong et al., 1985]. This contrast is important geochemically because at the sediment-water interface $\mathrm{IO}^{3-}$ is much more effectively absorbed by labile high molecular weight organic material than iodide, whereas $\mathrm{Br}^{-}$is absorbed by organic detritus independently of Eh. Thus sedimentary $\mathrm{I} / \mathrm{Br}$ is sensitive to the original oxygenation state of bottom water. Relatively high ratios indicate the presence of oxygen, while low ratios indicate its absence [Price and Calvert, 1977]. Furthermore, under anoxic conditions (such as those encountered in hemipelagic sediments below the oxic and suboxic surface layers) I is released by reactions with dissolved sulfide and humic substances [Francois, 1987]. $\mathrm{Br}$ is more conservative under such conditions [Pedersen and Price, 1980]. Such diagenetic overprinting lowers $\mathrm{I} / \mathrm{Br}$ with time (depth) in hemipelagic deposits, complicating the use of sedimentary $\mathrm{I} / \mathrm{Br}$ as an indicator of the bottom water oxygen content at the original time of deposition.

[13] In sediments at ODP Hole 1017E (Figure 2) $\mathrm{I} / \mathrm{Br}$ increases during stadial events. Dramatic enrichments occur before IS events 11 and 8, as well as several thousand years before the Bølling and during the Younger Dryas. In contrast, decreases in I/Br occur during the Bølling/Ållerød and the early Holocene, and at each interstadial event except IS 2, 4 and 13. There is a general upward increase in the ratio through the Holocene. A similar increase in the I content toward the sediment-water interface has previously been observed in Gulf of California sediments [Price and Calvert, 1973] and attributed to progressive loss of I with burial depth under anoxic conditions, as described above. It is probable that the first-order decline in $\mathrm{I} / \mathrm{Br}$ seen with depth in the Holocene section of ODP Hole 1017E reflects the same phenomenon, rather than a progressive change in bottom water oxygenation during the Holocene.

\subsection{Suboxic Indicators}

\subsubsection{Rhenium}

[14] Rhenium (Re) behaves conservatively in the ocean because of the nonreactive nature of perrhenate $\left(\mathrm{Re}(\mathrm{VII}) \mathrm{O}_{4}^{-}\right)$ in oxygenated water. In sediments, however, Re enrichments occur when $\mathrm{Re}(\mathrm{VII}) \mathrm{O}_{4}^{-}$is chemically reduced under suboxic conditions (i.e., prior to sulfate reduction) and sequestered in the solid phase, probably as $\mathrm{Re}(\mathrm{IV}) \mathrm{O}_{2}$ [Crusius et al., 1996]. Such accumulation is typically supported by downward diffusion from the overlying bottom waters [Calvert and Pedersen, 1993]. Re is found in very low concentrations in seawater, and thus diffusion is dramatically affected by changes in sedimentation rate, such that concentrations of the authigenic solid phase are reduced during times of rapid sedimentation.

[15] Re concentration in ODP Hole 1017E increases during most interstadial events (except IS 2, Figure 3); however, these enrichments do not necessarily coincide with interstadial initiations or terminations. Sharp increases in Re concentration occurred during the LGM at $\sim 22$ and 18 ka. No enrichment occurred during the Bølling, Allerød or Younger Dryas. A dramatic enrichment occurred at the beginning of the Holocene, with decreases evident between 9 and $7 \mathrm{ka}$ and after $2 \mathrm{ka}$ (Figure 3).

\subsubsection{Uranium}

[16] Uranium (U) also behaves conservatively in the ocean because of the nonreactive nature of the uranyl carbonate complex $\left(\mathrm{UO}_{2}\left(\mathrm{CO}_{3}\right)_{3},{ }^{4-}\right)$ in oxygenated water. $\mathrm{U}$ remains relatively nonreactive in sulphidic water despite the thermodynamically favored reduction of $\mathrm{U}(\mathrm{VI})$ to U(IV). It is thought that this might be due either to a need for particle surfaces to catalyze the reaction or for bacterial reduction, which occurs to a greater extent in sediments than in the water column [Calvert and Pedersen, 1993]. Thus $\mathrm{U}$ is delivered to the sediments either via settling of $\mathrm{U}$ bearing organic matter or downward diffusion from oxygenated bottom waters across the sediment-water interface, and into reducing sediments. Precipitation typically occurs below the depth of manganese and iron oxyhydroxide reduction, probably just at the depth where sulfate reduction begins [Klinkhammer and Palmer, 1991].

[17] The concentration of $U$ in the sediments correlates well with Re in the sediments of ODP Hole 1017E. The U concentration generally increases during interstadial events, while a general rise is evident during the LGM, and a sharp increase occurs at the beginning of the Holocene (Figure 3). Decreases occur during stadial events, IS 2, the Allerød, the Younger Dryas, between 9 and $7 \mathrm{ka}$ and after $2 \mathrm{ka}$. The U 


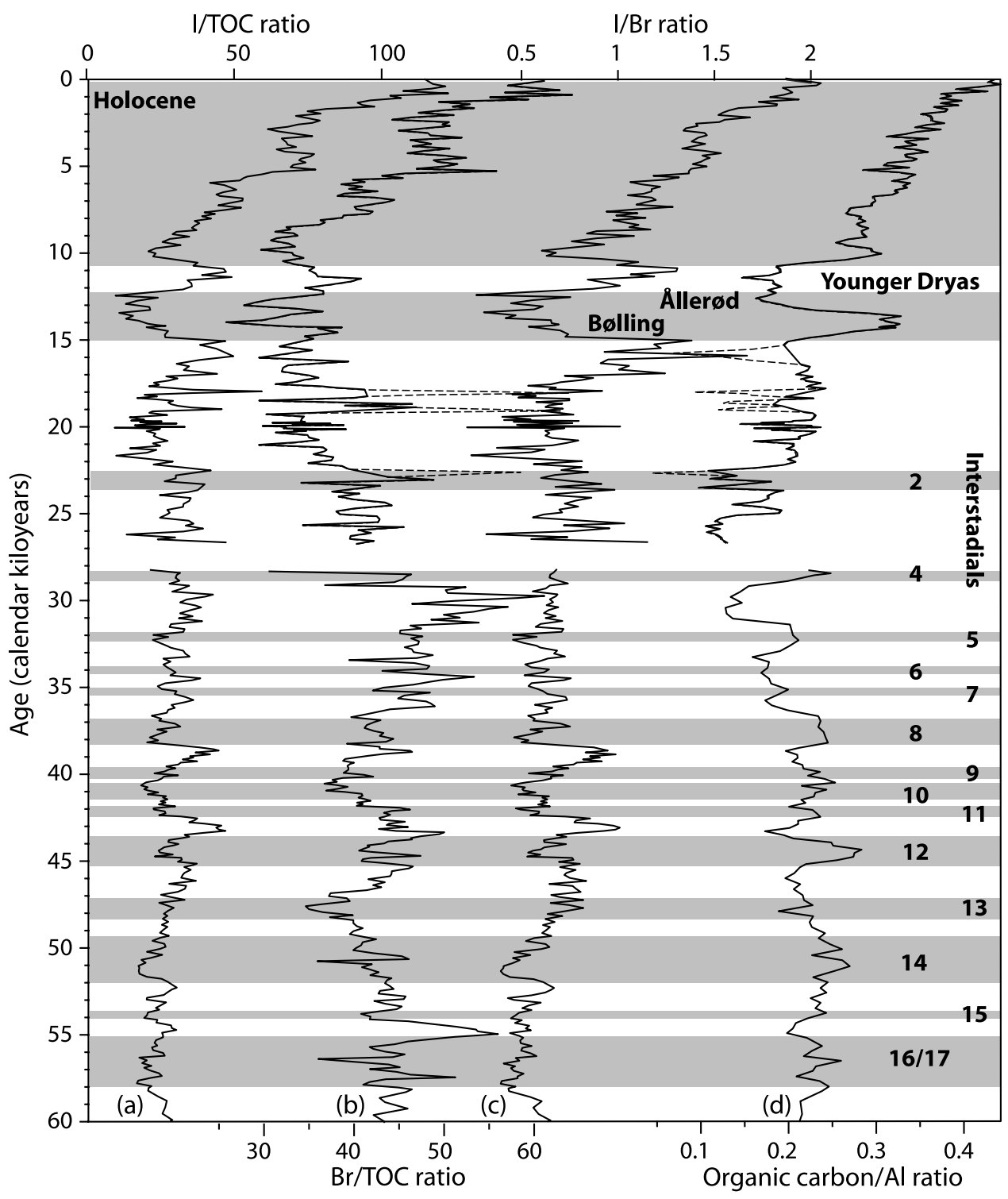

Figure 2. Comparison of the ratios of I to total organic carbon (labeled a), Br to total organic carbon (labeled b), I to Br (labeled c), and total organic carbon (labeled d) [Tada et al., 2000] during the last $60 \mathrm{kyr}$. Shading represents warm intervals as defined by the ratio of dextral to sinistral N. pachyderma. Interstadial events are numbered on the right. Dashed lines represent samples occurring within sand layers.

profile differs from that of Re most dramatically during the Bølling where an enrichment in $U$ occurs without a corresponding increase in Re concentration.

\subsubsection{Cadmium}

[18] The distribution of Cadmium $(\mathrm{Cd})$ in oceanic water columns is similar to phosphate, suggesting a direct participation in biological cycles, and implying an association with the soft parts of marine flora (i.e., diatoms and coccoliths [Boyle et al., 1976]). Enrichments of Cd in sediments have been suggested to result from the release of the metal into solution during degradation of biogenic material, followed by diffusion into suboxic or anoxic deposits and precipitation as a sparsely soluble sulfide phase [Rosenthal et al., 1995]. Such enrichments will only be observable above the lattice-bound background where sulfate reduction occurs at a relatively shallow subsurface depth. Thus sedimentary $\mathrm{Cd}$ enrichments can be attributed both to an increased sulfide presence and export productivity.

[19] Diagenetic burn down can complicate such primary signals in deposits where a decline in oxidant demand at the sediment-water interface (or increased advective supply of dissolved $\mathrm{O}_{2}$ in bottom water) drives an increased downward diffusive flux of oxygen. This can lead to postdepositional oxidation of authigenic $\mathrm{CdS}$, ephemeral release of $\mathrm{Cd}^{2+}$ to pore solution and its downward diffusion, and reprecipitation in the (deeper) sulfate-reducing zone [Thomson et al., 1996]. However, such redistribution does not occur at a significant rate where sedimentation rates are high $(>15 \mathrm{~cm}$ 


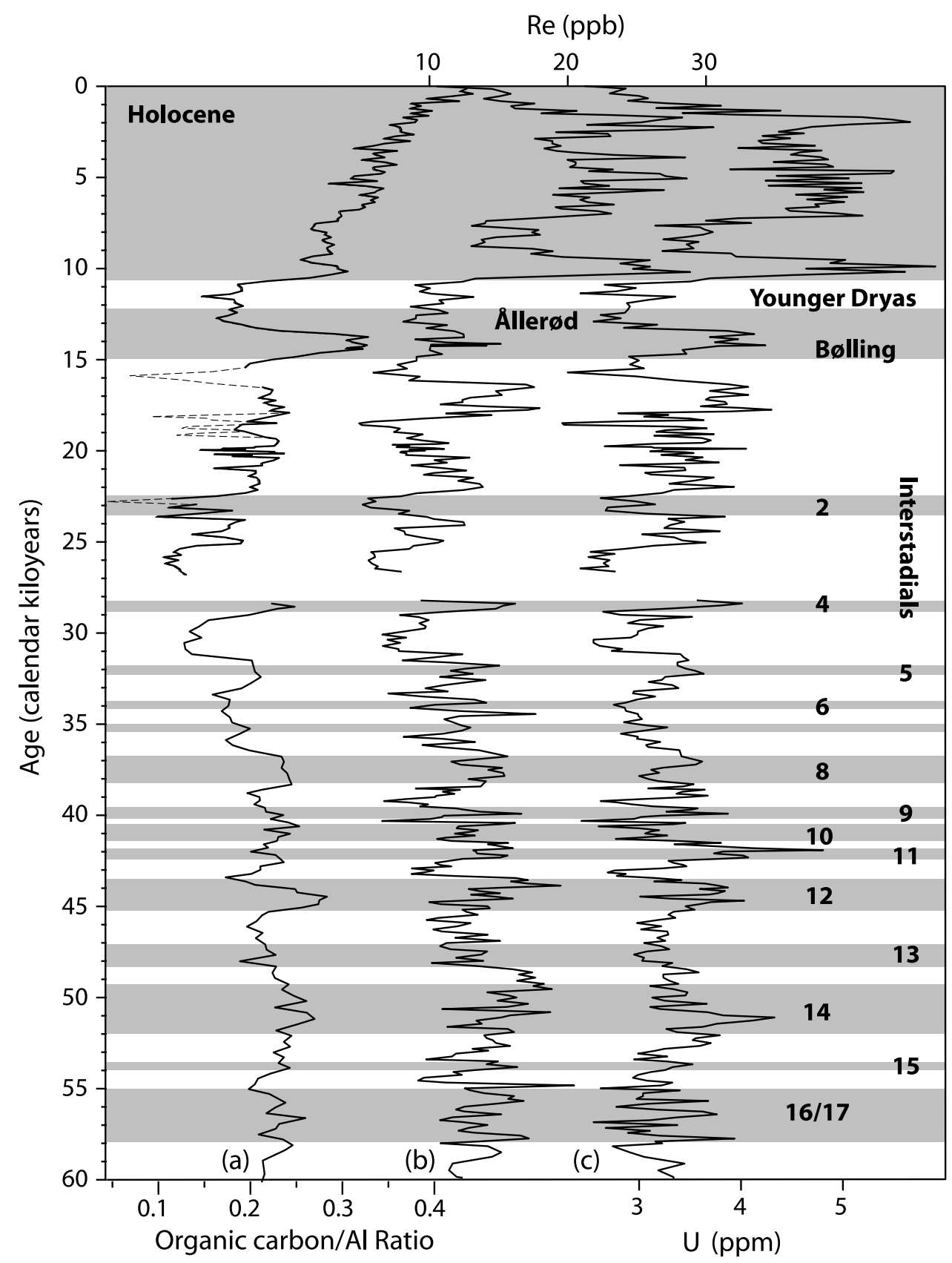

Figure 3. Comparison of records of total organic carbon (labeled a), Re (curve labeled b) (ppb), and U (labeled c) (ppm). Shading represents warm intervals as defined by the ratio of dextral to sinistral $N$. pachyderma. Interstadial events are numbered on the right. Dashed lines represent samples occurring within sand layers. Total concentrations of $\mathrm{Re}$ and $\mathrm{U}$ are shown rather than ratios to $\mathrm{Al}$ or $\mathrm{Ti}$ because of the similarity between the ratios and total concentrations (see section 2).

$\mathrm{kyr}^{-1}$ [Crusius and Thomson, 2003]) and has probably not impacted California Margin sediments.

[20] Enrichments in Cd (up to 1.5 ppb, Figure 4) occur in the sediments of ODP Hole 1017E during interstadial events 14, 12 to 4, during the LGM (22 to $17 \mathrm{ka}$ ), during the Bølling/Allerød, and at the beginning of the Holocene (particularly 10 to 8 and 4 to $2 \mathrm{ka}$ ). These enrichments occur in the same intervals as those of other metals (Re, $\mathrm{U}$ and $\mathrm{Ag}$ ), which argues further against overprinting by diagenetic burn down.

\subsubsection{Silver}

[21] Like $\mathrm{Cd}$, silver (Ag) appears to be involved in biological cycles and demonstrates nutrient-like behavior in oceanic water columns. Dissolved Ag correlates with silicic acid in the water column suggesting an association of Ag with plankton hard parts [Flegal et al., 1995]. This deduction is supported by culture experiments that demonstrate diatoms take up Ag more readily than coccolithophorids [Fisher and Wente, 1993]. Settling diatoms could therefore act as a delivery agent for $\mathrm{Ag}$ to the seafloor 


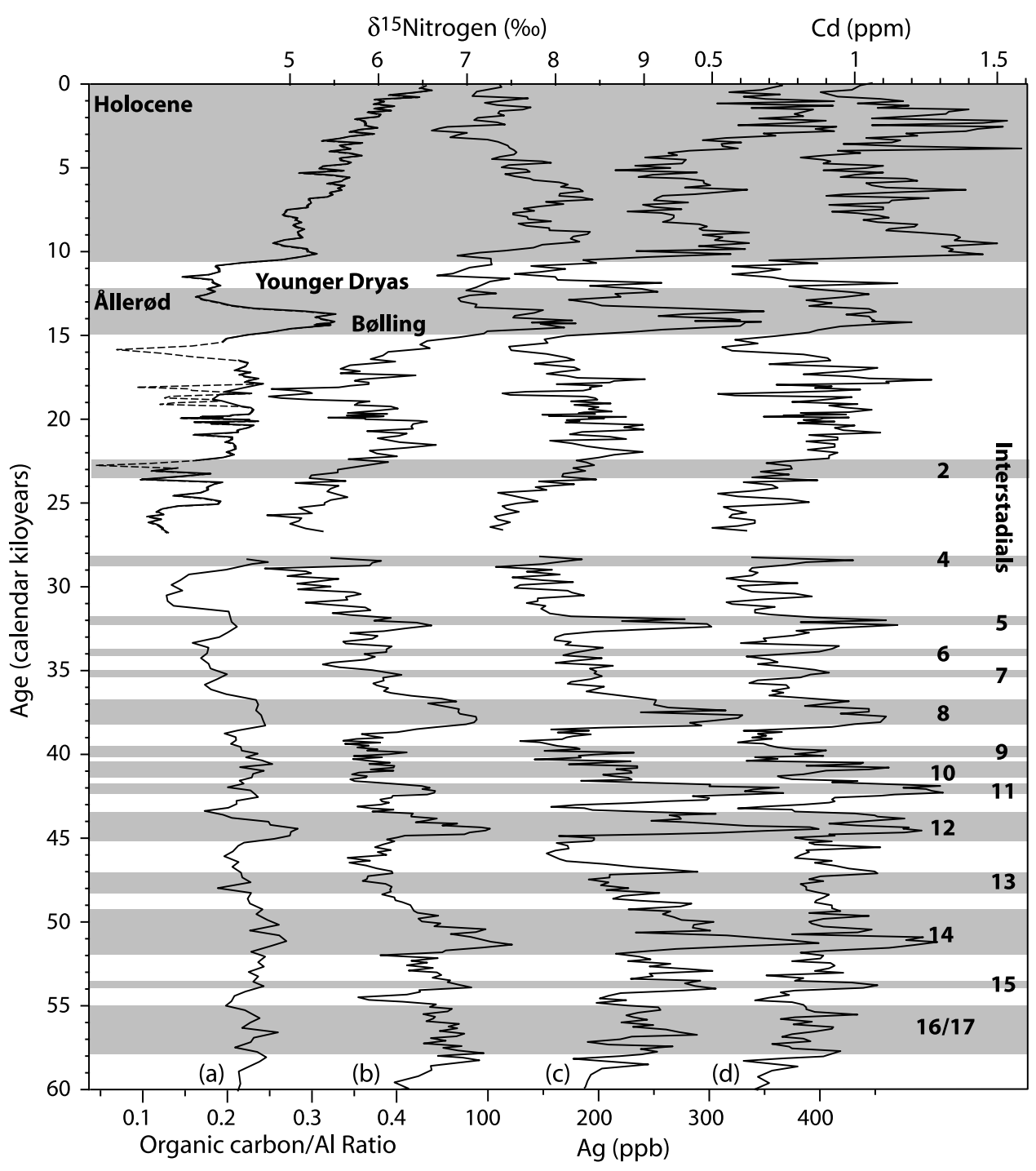

Figure 4. Comparison of records of total organic carbon (labeled a), $\delta^{15}$ nitrogen (labeled b), Ag (labeled c) (ppb), and Cd (labeled d) (ppm) for the last $60 \mathrm{kyr}$. Grey shading represents warm intervals as defined by the ratio of dextral to sinistral $N$. pachyderma. Interstadial events are numbered on the right. Dashed lines represent samples occurring within sand layers. Total concentrations of $\mathrm{Cd}$ and $\mathrm{Ag}$ are shown rather than ratios to $\mathrm{Al}$ or $\mathrm{Ti}$ because of the similarity between the ratios and total concentrations (see section 2).

raising the possibility that $\mathrm{Ag}$ could serve as a tracer for high diatom productivity, provided some fraction of the metal released by opal dissolution is captured as (highly insoluble) $\mathrm{Ag}_{2} \mathrm{~S}$. This simple and testable hypothesis is complicated by the recent observation that $\mathrm{Ag}$ concentrations in sediments also appear to be related to water column depth [McKay, 2003], suggesting that scavenging by settling particles may additionally contribute to the delivery of Ag to the seafloor.

[22] Where concentrations of dissolved $\mathrm{HS}^{-}$are sufficient, rates of accumulation of authigenic $\mathrm{Ag}$ and $\mathrm{Cd}$ are proportional to the concentration gradients of the metals in pore water. These gradients $\left(\delta \mathrm{C}_{\mathrm{Ag}} / \delta \mathrm{z}\right.$ and $\left.\delta \mathrm{C}_{\mathrm{Cd}} / \delta \mathrm{z}\right)$ are determined by the rate of release from decaying detritus at or near the sediment-water interface, and the rate and depth of precipitation in the subsurface. Thus vertical movements in the redox boundary (i.e., the onset depth of sulfate reduction) could cause sedimentary $\mathrm{Ag}$ and $\mathrm{Cd}$ concentration changes in the absence of variations in the delivery flux of opal, or soft-part detritus.

[23] The sedimentary Ag content in ODP Hole 1017E closely tracks that of $\mathrm{Cd}$ (Figure 4 ). Concentrations reach up to $350 \mathrm{ppb}$ (about 4 times the average lithogenic background) in IS events $14,12,11,8,4$, during the LGM, in the Bølling and at the beginning of the Holocene. This observed variability correlates more with indicators of export production, and in particular with $\delta^{15} \mathrm{~N}$ [Hendy et al., 2004] than any other paleotracer of suboxic conditions at the site.

\subsection{Anoxic Indicators: Molybdenum}

[24] Molybdenum occurs in seawater at relatively high concentrations $(\sim 100 \mathrm{nM})$ as the largely conservative 
molybdate anion, $\left(\mathrm{MoO}_{4}^{2-}\right)$. The main factor regulating the precipitation of this element in marine sediments appears to be the concentration of sulfide in pore waters [Zheng et al., 2000a, 2000b]. Thiomolybdate formation requires a threshold $\mathrm{H} 2 \mathrm{~S}$ concentration of $\sim 11 \mu \mathrm{M}$ [Erickson and Helz, $2000]$ and thus Mo enrichment, often in excess of $10 \mathrm{mg} / \mathrm{g}$, is associated with anoxic sediments in which sulfate reduction has occurred. Down-core measurements of Mo and $\mathrm{H}_{2} \mathrm{~S}$ in multicores recovered from Santa Barbara Basin provide support for this theoretical threshold [Zheng et al., 2000a]. At $\mathrm{HS}^{-}$levels of $\sim 11 \mu \mathrm{M}$, progressive substitution of sulphur for oxygen atoms in molybdate occurs, leading to the formation of multiple thiomolybdate species [Erickson and Helz, 2000]. This conversion promotes Mo sequestration by the solid phase, possibly via adsorption of particlereactive thio species onto particle surfaces, or coprecipitation with Fe-sulfide [Zheng et al., 2000a]. Mo may form a separate insoluble sulfide phase, possibly $\mathrm{MoS}_{3}$, when FeS is converted to pyrite during subsequent reaction with elemental S or polysulfides. At high sulfide concentrations $(\sim 100 \mu \mathrm{M})$ and in the absence of dissolved iron, precipitation of Mo continues, perhaps as a discrete Mo-sulfide phase [Zheng et al., 2000a].

[25] At ODP Hole 1017E enrichments in Mo occur during major interstadial events (IS 14, 12, 11, 8, and 5, Figure 5). There is a general increase in Mo throughout the LGM, with sharp, short intervals of enrichments occurring immediately below thin sand layers that characterize the interval [Irino and Pedersen, 2000; Tada et al., 2000]. A pronounced enrichment of 5 ppm occurs during the Bølling, followed by a general increase toward the mid-Holocene $(\sim 6 \mathrm{ka})$. Concentrations progressively decline to $\sim 3 \mathrm{ppm}$ over the last several thousand years of deposition.

\section{Discussion}

[26] The origin of millennial-scale changes in oxygen minimum zone (OMZ) strength along the California Margin [Ivanochko and Pedersen, 2004; van Geen et al., 1996; Zheng et al., 2000b] has remained a source of contention. One hypothesis maintains that the OMZ was physically controlled by changes in intermediate water source strength and/or composition in the North Pacific [Cannariato and Kennett, 1999; Crusius et al., 2004; Kennett and Ingram, 1995]. While a second hypothesis [Ortiz et al., 2004] argues for a biological control of the OMZ through the decay of organic matter generated by coastal upwelling export production resulting in subsurface water oxygen consumption.

[27] In support of the former hypothesis Ivanochko and Pedersen [2004] found that Holocene anoxic sediments in Santa Barbara Basin resulted from a combination of limited bottom water renewal and high primary productivity. However, there is little evidence from the flux of organic carbon $\left(\mathrm{C}_{\text {org }}\right)$ that anoxic events were triggered by increased productivity during interstadials of the last $50 \mathrm{kyr}$. In contrast Hendy et al. [2004] recently demonstrated that warm events including interstadials were marked by increased productivity at Point Conception, just north of Santa Barbara Basin. In addition Berger et al. [2004] suggest that sediment takes a circuitous route before being deposited in Santa Barbara Basin, complicating any interpretation of $\mathrm{C}_{\text {org }}$ content. Combined, these studies suggest that the relative influence of ventilation and productivity on the $\mathrm{OMZ}$ of the southern California Margin should be reexamined.

[28] Redox conditions that drive sedimentary trace element concentrations are determined by a number of influences including sedimentation rate, primary productivity, water column oxygen concentration and relative changes in metal concentrations in water masses. Given that the response of each trace element typically differs slightly with each influence, simultaneous comparison of the down-core sedimentary signals of a number of trace elements can shed light on the temporal behavior and influence of each process. The upper $12 \mathrm{~m}$ of ODP Hole 1017E contain a rich set of signals that illuminate such controls, and these are discussed in the following section. Temporal changes in export production and variability in intermediate water oxygen supply are emphasized. Such controls are discussed on an individual basis. This is an inadequate approach given that it tends to mask the degree to which the various influences are interrelated. Thus, wherever possible, the collective impact is highlighted.

\subsection{Export Production, Organic Matter Delivery Rate, and Bulk Sediment Accumulation}

[29] Hendy et al. [2004] recently described the history of primary production at ODP Site 1017, using sedimentary trace element, organic carbon, biogenic opal and carbonate concentrations, bulk sediment $\delta^{15} \mathrm{~N}$, planktonic foraminiferal species assemblage and carbon isotope determinations to conclude that the rate of nutrient delivery to the euphotic zone has strongly controlled productivity in the region over the last $60 \mathrm{kyr}$. According to this interpretation, increased productivity associated with upwelling occurred at the site mainly during the warm intervals of the last $60 \mathrm{kyr}$. As discussed by those authors, the $\mathrm{C}_{\text {org }}$ profile shown in Figure 3 can be used as a first-order proxy for export production.

[30] $\mathrm{C}_{\text {org }}$ deposition at Point Conception (ODP Hole 1017E) varies significantly from that of Santa Barbara Basin (ODP Hole 893A). $\mathrm{C}_{\text {org }}$ at ODP Hole 1017E is closely correlated to grain size, while the $\mathrm{C}_{\text {org }}$ profile from ODP Hole 893A shows no correlation. Thus care is taken by Hendy et al. [2004] to demonstrate that $\mathrm{C}_{\text {org }}$ shifts are not the result of either dilution or preservation. After normalization to grain size, $\mathrm{C}_{\text {org }}$ varies in concert with sedimentary $\delta^{15} \mathrm{~N}$, relative abundance of upwelling-related planktonic foraminiferal species abundance, biogenic opal content and sea surface temperature as indicated by the coiling ratio of N. pachyderma [Hendy et al., 2004]. Furthermore, the $\mathrm{C}_{\mathrm{org}}$ increases during "bloom" events inferred from the planktonic foraminiferal $\delta^{13} \mathrm{C}$ data [Hendy et al., 2004]. Together these data support the interpretation that down-core $\mathrm{C}_{\text {org }}$ maxima represent upwelling-induced enhanced organic matter export from surface waters. Although there is no similarity between the $\mathrm{C}_{\text {org }}$ profile at ODP Hole 1017E and 893A, agreement in planktonic foraminiferal census data between the sites suggests that Santa Barbara Basin surface waters also experienced increased productivity during interstadial events [Hendy and Kennett, 2000; Hendy et al., 2004].

[31] The variations in carbon flux implied by the ODP Hole 1017E data should have influenced the chemistry of 


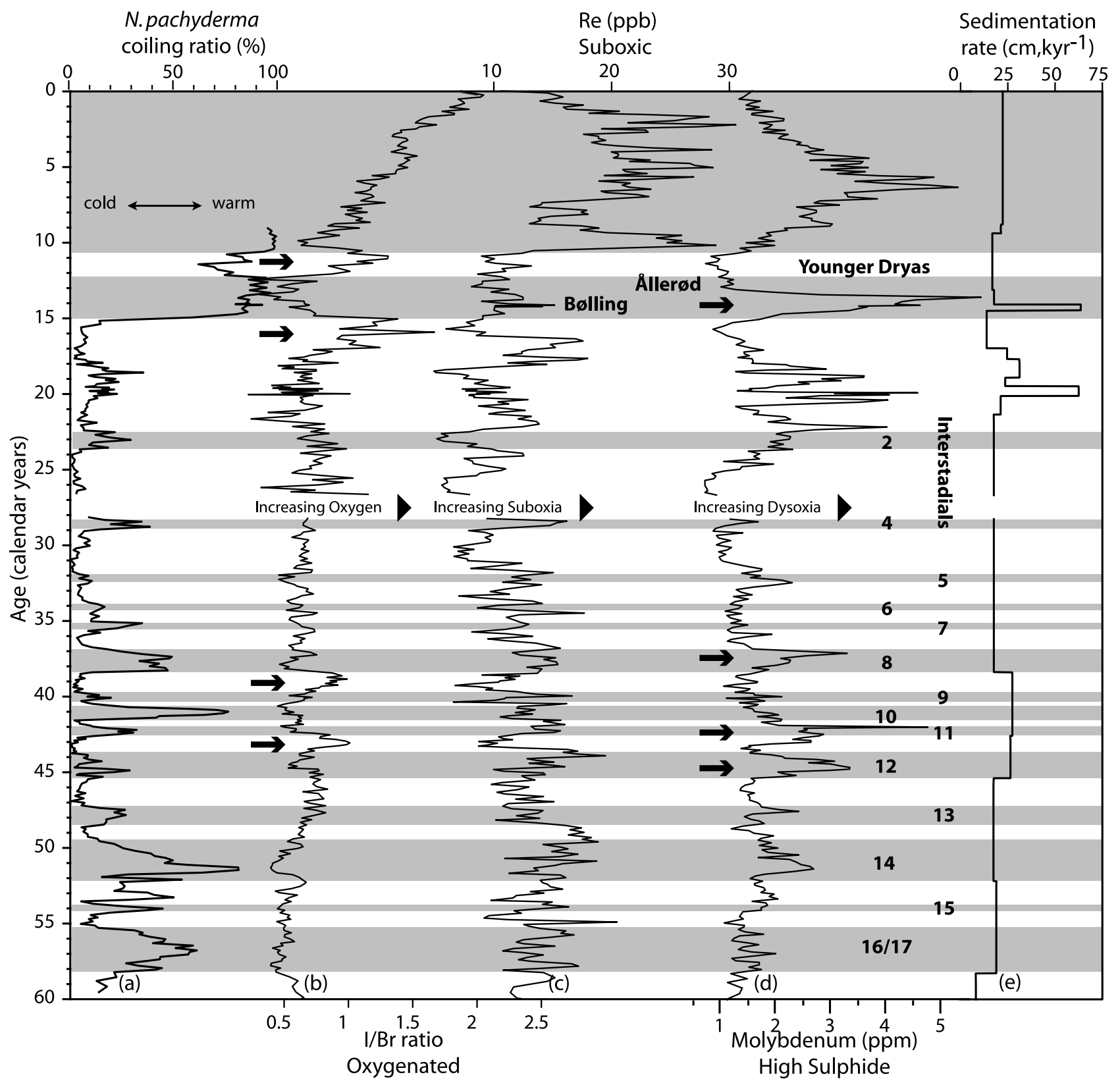

Figure 5. Comparison of records of the ratio of dextral to sinistral N. pachyderma (labeled a), ratio of I to $\mathrm{Br}$ (labeled b), Re (labeled c) (ppb), Mo (ppm) (labeled d) and sedimentation rate (labeled d) for the last 60 kyr. Shading represents warm intervals as defined by the ratio of dextral to sinistral $N$. pachyderma. Interstadial events are numbered on the right. Bold arrows represent intervals highlighted in the discussion.

the underlying sediments, given that labile organic carbon supply is a fundamental (although not unique) control on authigenic trace metal contents of continental margin sediments. Changes in the rate of supply can strongly influence the depth to the onset of suboxia and anoxia in the subsurface sediments. When the settling flux of carbon is high (all other factors being equal) the upper surface of the sulfatereducing zone will shoal, shortening the path length for downward diffusion of metals from bottom or interface waters to the underlying sulfide-bearing pore waters. Enhanced precipitation of sulfide-reactive metals (e.g., Ag,
Cd or Mo) will then increase their bulk concentrations in the deposits [Pedersen et al., 1989]. Elements that are reduced and precipitate at a higher (suboxic) Eh (e.g., Re) should also become relatively enriched under such conditions.

[32] Where the rate of $\mathrm{C}_{\text {org }}$ accumulation is constant increases in the rate of bulk sedimentation can in principle accomplish the same result by more quickly burying labile organic matter below the aerobic zone. This requires electron transfer to oxidants other than $\mathrm{O}_{2}$, thus driving down the Eh. However, a complication here is that increased bulk sedimentation dilutes the authigenic component. The authi- 
genic fraction of redox active elements, such as Re that are scarce in seawater can be proportionately smaller under such conditions. This can be seen in the Bølling (about $14 \mathrm{ka}$ ) and in earlier brief intervals centered on $\sim 18$ and $\sim 20 \mathrm{ka}$, where pronounced Mo enrichments (reflecting strongly reducing conditions and high pore water sulfide concentrations) are not accompanied by high Re concentrations (Figure 5). In all three intervals, the ${ }^{14} \mathrm{C}$-derived linear sedimentation rate was higher (Figure 5, far right) implying that rapid sedimentation of bulk sediments drove the near-surface deposits toward highly reducing conditions. These events appear to have persisted for several centuries to millennia. High $\mathrm{C}_{\text {org }}$ content in the Bølling suggests very high export production at that time [see Hendy et al., 2004] commensurate with rapid sedimentation, while low $\mathrm{C}_{\text {org }}$ values at 18 and $20 \mathrm{ka}$ impute a major effect from rapid sedimentation alone. MIS 2 (21 to $18 \mathrm{ka}$ ) at Site 1017 is associated with thin sand layers, and their episodic, but rapid, deposition probably reflects the low sea level and transgressive shoreline that was characteristic of LGM. Irino and Pedersen [2000] have previously suggested that climatic conditions during the LGM would have strengthened littoral drift along the California Margin increasing sand deposition at the site.

\subsection{Oxygen Concentration in Bottom Waters}

\subsubsection{Hydrography}

[33] The bottom water that bathes Site 1017 today lies within the lower regions of the oxygen minimum zone (OMZ). In contrast, ODP Hole 893A is located in the core of the OMZ, and within a basin with restricted bottom water movement. The OMZ is biologically controlled by the degradation of raining organic material and physically controlled lateral advection of low oxygen water into the region. The relative influence of biological or physical control on sedimentary redox chemistry is dependent on the location of the site within the OMZ. Sites located in the core of the OMZ mostly impacted by advected water mass characteristics and those at the fringes are more influenced by biological processes. On the California Margin, advected water mass characteristics are related to the California Undercurrent. This current carries warm, salty, low oxygen water northwestward along the continental slope from Baja California to Vancouver, Canada [Chelton, 1984; Hickey, 1979; Tisch et al., 1992]. Although its core lies around 200-300 m depth, poleward flow in the area has been recorded as deep as $1500 \mathrm{~m}$ [Bray and Greengrove, 1993], some $500 \mathrm{~m}$ deeper than Site 1017.

[34] The northwest Pacific also plays a role in the hydrography of the waters at $1 \mathrm{~km}$ depth off southern California. Well ventilated intermediate water forms in the Bering Sea [Takahashi, 1998], the Sea of Okhotsk [Talley, 1991] and the Alaskan Gyre [Van Scoy et al., 1991a] through processes of sea ice formation and vertical mixing. These waters flow both along streamlines in easterly and southerly directions and are known to reach the western margin of North America [Chelton, 1984; Hickey, 1979; Reid, 1965]. Previous work at ODP Hole 893A (Santa Barbara Basin) has demonstrated that the oxygen content of the basin fluctuated during the Dansgaard-Oeschger cycles of the last glacial because of a combination of changes in surface water productivity and intermediate water ventilation [Behl and Kennett, 1996; Cannariato and Kennett, 1999; Ivanochko and Pedersen, 2004; Kennett and Ingram, 1995] that appear to have been driven by physical processes in the northwestern reaches of the Pacific. The oxygen content of intermediate waters that originate in this region can also be influenced by biology. Recent work by Crusius et al. [2004] suggests that enhanced productivity off Hokkaido and Kamchatka during the Bølling, for example, may have diminished the oxygen content of intermediate waters exported from the region to the western coast of North America. Thus the oxygen content of water overlying ODP Site 1017 through the late Quaternary may have been controlled by the lateral advection of intermediate waters from both the eastern tropical and remote northwest Pacific, with the relative proportions of each varying through time (Figure 1), as well as by the vertical flux of settling organic matter. The challenge is to distinguish the influence of lateral advection from that of the vertical detrital rain.

\subsubsection{Geochemical Evidence for Controls on the Bottom Water Oxygen Content}

[35] The relative importance of advective (physical) oxygen supply versus consumption driven by (biological) vertical rain at ODP Site 1017 is best illustrated by the contrast between the Bølling, the Allerød and the Younger Dryas (Figure 5). This interval can be identified as a period where inferred pore water oxygen content and productivity indicators decouple. As described above, the strong export production indicated for the Bølling waned at the beginning of the Allerød (13.5 to $12 \mathrm{ka}$ ), and relatively weak productivity continued through the Younger Dryas (12 to $10.5 \mathrm{ka}$, Figure 4). The Mo profile indicates strongly reducing conditions in the near-surface deposits during the Bølling, while low $\mathrm{I} / \mathrm{Br}$ values in the same interval imply severe oxygen depletion in the bottom waters. Low $\mathrm{I} / \mathrm{Br}$ values persisted through the Allerød ( $13 \mathrm{ka})$, despite the apparent decline in local export production indicated by the drop in organic carbon content at ODP hole 1017E. It is possible that continuing advection of oxygen-depleted waters from the North Pacific [Crusius et al., 2004] or the eastern tropical Pacific [Hendy and Kennett, 2003] accounted for the suboxia implied by the $\mathrm{I} / \mathrm{Br}$ data. Low Mo concentrations indicate that the near-interface pore waters were not strongly reducing in the same time interval (at $\sim 13 \mathrm{ka}$ ), which is attributed to a sharp drop in the settling flux of organic matter and associated oxidant demand at and just below the seafloor.

[36] At the Younger Dryas $(\sim 12 \mathrm{ka})$ the bottom water oxygen content increased sufficiently to promote relative enrichment of I. The accompanying low Re and Mo concentrations, indicate that the upper pore waters were oxygenated in addition to the bottom water. The near constancy of the organic carbon content and the sedimentation rate between 13 and $10.5 \mathrm{ka}$ (Figure 2) rule out local production (the vertical organic rain) as the primary influence on bottom water oxygen concentration during this interval. Collectively these data imply that the oxygen content at 
the seafloor was driven primarily by lateral advection of water derived from distal locales during deglaciation.

[37] The picture changed dramatically at the beginning of the Holocene. Sharp (and relatively rapid) increases in $\mathrm{C}_{\text {org }}$ and Re concentration imply significantly increased export production and reestablishment of shallow suboxia in the pore waters (Figure 5). A decline in the $\mathrm{I} / \mathrm{Br}$ ratio between 10.5 and $9.5 \mathrm{ka}$ implies a simultaneous but relatively shortlived depletion in bottom water oxygen. This may have been related to the increased vertical rain of organic detritus, but lateral advection cannot be ruled out. On the basis of the $\mathrm{C}_{\text {org }}$ content, export production remained high for the rest of the Holocene, but was insufficient to drive bottom waters to the point where I sequestration ceased, as indicated by the relatively high $\mathrm{I} / \mathrm{Br}$ ratio between $\sim 8 \mathrm{ka}$ and the core top.

[38] Together the data imply a significant lateral delivery of oxygen to ODP Hole 1017E for most of the Holocene. Variations in Mo and Re concentration during this interval show that the oxidant demand (thus intensity of anoxia) varied, being highest in the mid-Holocene when Mo concentration in the deposit reached $\sim 5 \mathrm{ppm}$. There is no commensurate decline in the $\mathrm{I} / \mathrm{Br}$ and thus bottom water remained oxygenated. The interval of high Mo content may, as discussed earlier, reflect an increased bulk sedimentation rate. The absence of chronological control above 8 ka does not allow this possibility to be assessed.

\subsection{Metal Delivery to the Seafloor}

[39] A very strong correlation can be seen throughout MIS 3 at ODP Site 1017 among bulk sediment $\delta^{15} \mathrm{~N}$ and sedimentary $\mathrm{Cd}, \mathrm{Ag}$ and $\mathrm{C}_{\text {org }}$ concentrations (Figure 4); high $\delta{ }^{15} \mathrm{~N}$ values in particular are faithfully tracked by enrichments in both $\mathrm{Cd}$ and $\mathrm{Ag}$. The explanation for this parallel behavior lies in the link between upwelling and export production [Hendy et al., 2004]. High $\delta^{15} \mathrm{~N}$ values (assuming complete nitrate utilization) signal the northward transport of denitrified water in the California Undercurrent from the eastern tropical Pacific, as previously inferred by Altabet et al. [1999] and Kienast et al. [2002]. Upwelling of this water contributes a component of isotopically enriched nitrate to the euphotic zone, which is reflected in the high $\delta^{15} \mathrm{~N}$ of plankton in the area [Altabet et al., 1999]. Other characteristics of this water mass include low oxygen and high nutrient concentrations. It is reasonable to assume that these waters also contain relatively higher concentrations of $\mathrm{Cd}$ and $\mathrm{Ag}$ than mode waters that form off the coast of Japan, given that both metals are nutrient analogues (see sections 3.2.3 and 3.2.4).

[40] Upwelling results not only in stimulation of phytoplankton production but also enhanced uptake of $\mathrm{Cd}$ and $\mathrm{Ag}$ by plankton cells and consequent vectoring to the seafloor by sinking detritus. Therefore the correlations among $\mathrm{C}_{\mathrm{org}}$, $\delta^{15} \mathrm{~N}, \mathrm{Cd}$ and $\mathrm{Ag}$ are directly related to euphotic zone production through upwelling. A record of $\mathrm{Ag}$ and $\mathrm{Cd}$ delivery will only be retained by the sediments where the concentration of bisulfide ion in shallow pore waters is sufficient to fix the metals into the solid phase as they are released by decomposition of cells $(\mathrm{Cd})$ or dissolution of frustules (Ag). The presence of sulfide is confirmed by the Mo profile (Figure 5). Therefore nonconservative trace metal concentrations at ODP Site 1017 clearly demonstrate a link between high productivity and the varying nutrient content of upwelled subsurface water masses.

[41] Correlations among the $\delta^{15} \mathrm{~N}, \mathrm{Cd}, \mathrm{Ag}$ and $\mathrm{C}_{\text {org }}$ persist through MIS 2 and the Bølling, to the early Holocene, implying that export production continued to act as a conveyor of both metals to the seafloor during the interval of $24 \mathrm{ka}$ to $\sim 7 \mathrm{ka}$. Over the last several thousand years, however, the correlation breaks down: $\mathrm{Ag}$ and $\mathrm{Cd}$ concentrations covary with $\delta^{15} \mathrm{~N}$ while the $\mathrm{C}_{\text {org }}$ concentration consistently increases toward the present. We speculate that this may reflect relatively rapid loss of organic carbon in the upper reaches of the sediment column via early diagenetic decomposition, i.e., over the last few thousand years.

\section{Conclusions}

[42] The application of multiproxy data sets at ODP Hole 1017E off Point Conception, California, confirms a strong link between the surface waters off southern California and the underlying slope sediments $(\sim 1 \mathrm{~km}$ water depth $)$ throughout the late Quaternary. This relationship is demonstrated by significant correlations between the following proxies: organic carbon (fundamentally an indicator of surface water processes); $\mathrm{I} / \mathrm{Br}$ (an indicator of past sediment-water interface oxygenation history); Mo concentrations (a reflection of the intensity of upper sediment column anoxia); and the sedimentary Ag and Cd contents (primarily thought to represent the delivery flux of the metals to the seafloor in biologic detritus).

[43] The use of multiple tracers, representing a spectrum of biologic and geochemical processes, defines episodes of low pore water oxygen concentrations during the last $60 \mathrm{kyr}$ in agreement with previous studies [Cannariato and Kennett, 1999; Crusius et al., 2004; Ivanochko and Pedersen, 2004; Kennett and Ingram, 1995]. Productivity proxies (planktonic foraminiferal assemblages, $\mathrm{C}_{\text {org }}$, biogenic opal, and carbonate concentrations) reveal a close correlation between enhanced export production and pore water oxygen deficits (increased trace metal accumulation) during the larger interstadial events of the last glacial, lending support to the contention that export production played an important role in OMZ strength [Cannariato and Kennett, 1999; Ortiz et al., 2004].

[44] Concentrations of $\mathrm{Ag}$ and $\mathrm{Cd}$ increased dramatically during many interstadial events in MIS 3 and the Bølling, and correlate closely with high $\delta^{15} \mathrm{~N}$ values in bulk sediments. The latter is interpreted as fundamentally reflecting the appearance during upwelling of the nutrient rich (and ${ }^{14} \mathrm{NO}_{3}^{-}$depleted) southern source water. We suggest the appearance of this water mass in southern Californian surface waters enhances export production and consequently the delivery of $\mathrm{Ag}$ and $\mathrm{Cd}$ to the seafloor via sinking planktonic debris. Increased oxidant demand associated with this flux promotes sulfate reduction in the near-surface sediments. This, in turn, leads to fixation of $\mathrm{Ag}$ and $\mathrm{Cd}$ sulfides, and the sequestration of Mo during intervals of pronounced high productivity.

[45] $\mathrm{I} / \mathrm{Br}$ data show that the oxygen concentration in the bottom waters at ODP Site 1017 varied between oxygenated and suboxic during cool, low-productivity intervals of the 
last glacial. However, we can demonstrate for the first time that productivity and bottom water oxygen content became decoupled during deglaciation at Site 1017. During the Allerød (13.5 to $12 \mathrm{ka}$ ), low $\mathrm{I} / \mathrm{Br}$ values parallel low $\mathrm{C}_{\text {org }}$ content implying decreased local export production at the same time as suboxic water was imported from a remote source. At the onset of the Younger Dryas oxygen concentrations in bottom waters increased with no inferred change in productivity. Thus we also support the assertion that the ventilation of intermediate waters did play a role in $\mathrm{OMZ}$ strength on the North American margin [Cannariato and Kennett, 1999; Crusius et al., 2004; Ivanochko and Pedersen, 2004; Kennett and Ingram, 1995].

[46] Acknowledgments. T.F.P. is grateful to the Natural Sciences and Engineering Research Council of Canada and the Faculty of Graduate Studies at the University of British Columbia for partial funding of this research. This research used samples provided by the Ocean Drilling Program (ODP). ODP is sponsored by the United States National Science Foundation (NSF) and participating countries under the management of the Joint Oceanographic Institutes (JOIs) INC.

\section{References}

Altabet, M. A., C. Pilskaln, R. Thunell, C. Pride, D. Sigman, F. Chavez, and R. Francois (1999), The nitrogen isotope biogeochemistry of sinking particles from the margin of the eastern North Pacific, Deep Sea Res., Part I, $46,655-679$.

Behl, R. J., and J. P. Kennett (1996), Evidence for brief interstadial events in the Santa Barbara Basin, NE Pacific during the past 60 kyr, Nature, 379, 243-246.

Berger, W. H., A. Schimmelmann, and C. B Lange (2004), Tidal cycles in the sediments of Santa Barbara Basin, Geology, 32, 329332.

Berner, R. A. (1980), Early Diagenesis: A Theoretical Approach, 241 pp., Princeton Univ. Press, Princeton, N. J.

Boyle, E. A., F. Sclater, and J. M. Edmond (1976), Marine geochemistry of cadmium, Nature, 263, 42-44.

Bray, N. A., and C. L. Greengrove (1993), Circulation over the shelf and slope off northern California, J. Geophys. Res., 98, 18,11918,145 .

Calvert, S. E. (1984), Elemental analyses, in Sedimentology, Physical Properties and Geochemistry in the Initial Reports of the Deep Sea Drilling Project, Volumes 1-44: An Overview, edited by G. R. Heath, pp. 177-191, Scripps Inst. of Oceanogr., La Jolla, Calif.

Calvert, S. E., and T. F. Pedersen (1993), Geochemistry of Recent oxic and anoxic sediments: Implications for the geological record Mar: Geol., 113, 67-88.

Cannariato, K. G., and J. P. Kennett (1999), Climatically related millennial-scale fluctuation in the strength of the California margin oxygen-minimum zone during the past $60 \mathrm{k} . \mathrm{y}$., Geology, 27, 975-978.

Chelton, D. B. (1984), Seasonal variability of along-shelf geostrophic velocity off central California, J. Phys. Oceanogr., 12, 757-784

Crusius, J., and J. Thomson (2003), Mobility of authigenic rhenium, silver, and selenium during postdepositional oxidation in marine sediments, Geochim. Cosmochim. Acta, 67 $265-273$.

Crusius, J., S. E. Calvert, T. F. Pedersen, and D. Sage (1996), Rhenium and molybdenum enrichments in sediments as indicators of oxic, suboxic and anoxic conditions of deposition, Earth Planet. Sci. Lett., 145, 65-78.

Crusius, J., T. F. Pedersen, S. Kienast, L. Keigwin, and L. Labeyrie (2004), Influence of northwest Pacific productivity on North Pacific Intermediate Water oxygen concentrations during the Bølling-Allerød interval (14.7-12.9 ka), Geology, 32, 633-636.

Erickson, B. E., and G. R. Helz (2000), Molybdenum(VI) speciation in sulfidic waters:
Stability and lability of thiomolybdates, Geochim. Cosmochim. Acta, 64, 1149-1158.

Fisher, N. S., and M. Wente (1993), The release of trace elements by dying marine phytoplank ton, Deep Sea Res., Part I, 40, 671-694.

Flegal, A. R., S. A. Sanudo-Wilhelmy, and G. M. Scelfo (1995), Silver in the eastern Atlantic Ocean, Mar. Chem., 49, 315-320.

Francois, R. (1987), The influence of humic substances on the geochemistry of iodine in nearshore and hemipelagic marine-sediments, Geochim. Cosmochim. Acta, 51, 2417-2427.

Gardner, J. V., W. E. Dean, and P. Dartnell (1997), Biogenic sedimentation beneath the California Current system for the past $30 \mathrm{kyr}$ and its paleoceanographic significance, Paleoceanography, 12, 207-225.

Hendy, I. L., and J. P. Kennett (2000), Dansgaard/ Oeschger Cycles and the California Current system: Planktonic foraminiferal response to rapid climate change in Santa Barbara Basin, ODP Hole 893A, Paleoceanography, 15, 3042

Hendy, I. L., and J. P. Kennett (2003), Tropical forcing of North Pacific Intermediate Water during late Quaternary climate change, Quat Sci. Rev., 22, 673-689.

Hendy, I. L., T. F. Pedersen, J. P. Kennett, and R. Tada (2004), Intermittent existence of a southern Californian upwelling cell during submillennial climate change of the last $60 \mathrm{kyr}$, Paleoceanography, 19, PA3007, doi:10.1029/ 2003PA000965.

Hickey, B. M. (1979), The California Current system: Hypotheses and facts, Prog. Oceanogr., 8, 191-279.

Irino, T., and T. Pedersen (2000), Geochemical character of glacial to interglacial sediments at Site 1017, southern Californian Margin: Minor and trace elements, Proc. Ocean Drill. Program Sci. Results, 167, 263-271.

Ivanochko, T. S., and T. F. Pedersen (2004), Determining the influences of late Quaternary ventilation and productivity variations on Santa Barbara Basin sedimentary oxygenation: A multi-proxy approach, Quat. Sci. Rev., 23, 467-480.

Keigwin, L. D. (1998), Glacial-age hydrography of the far northwest Pacific Ocean, Paleoceanography, 13, 323-339.

Kennett, J. P., and B. L. Ingram (1995), A 20,000-year record of ocean circulation and climate change from the Santa Barbara Basin, Nature, 377, 510-514.

Kennett, J., E. Roark, K. Cannariato, B. Ingram, and R. Tada (2000), Latest Quaternary paleoclimatic and radiocarbon chronology, Hole 1017E, southern California margin, Ocean Drill. Program Initial Rep., 167, 249-254.

Kienast, S. S., S. E. Calvert, and T. Pedersen (2002), Nitrogen isotope and productivity var- iations along the northeast Pacific margin over the last 120 kyr: Surface and subsurface paleoceanography, Paleoceanography, 17(4), 1055, doi:10.1029/2001PA000650.

Klinkhammer, G. P., and M. R. Palmer (1991), Uranium in the oceans: Where it goes and why, Geochim. Cosmochim. Acta, 55, 17991806

Lund, D. C., and A. C. Mix (1998), Millennialscale deep water oscillations: Reflections of the North Atlantic in the deep Pacific from 10 to $60 \mathrm{ka}$, Paleoceanography, 13, 10-19.

McKay, J. L. (2003), Palaeoceanography of the northeastern Pacific Ocean off Vancouver Island, Ph.D. thesis, Univ. of B. C., Vancouver, B. C., Canada.

Noble, M. A., and S. R. Ramp (2000), Subtidal currents over the central California slope: Evidence for offshore veering of the undercurrent and for direct, wind-driven slope currents, Deep Sea Res., Part II, 47, 871-906.

Ortiz, J. D., S. O'Connell, J. Del Viscio, W. Dean, J. Carriquiry, T. Marchitto, Y. Zheng, and A. van Geen (2004), Enhanced marine productivity off western North America during warm climate intervals of the past $52 \mathrm{kyr}$, Geology, 32, 521-524.

Pedersen, T. F., and N. B. Price (1980), The geochemistry of iodine and bromine in sediments of the Panama Basin, J. Mar. Res., 38, 397-411.

Pedersen, T. F., R. Waters, and R. W. Macdonald (1989), On the natural enrichment of cadmium and molybdenum in the sediments of Ucluelet Inlet, British Columbia, Sci. Total Environ., 79, $125-139$.

Price, N. B., and S. E. Calvert (1973), Geochemistry of iodine in oxidized and reduced Recent marine sediments, Geochim. Cosmochim. Acta, 37, 2149-2158.

Price, N. B., and S. E. Calvert (1977), Contrasting geochemical behaviors of iodine and bromine in Recent sediments from Namibian Shelf, Geochim. Cosmochim. Acta, 41, $1769-1775$

Reid, J. L. (1965), Intermediate Waters of the Pacific Ocean, 85 pp., Johns Hopkins Univ. Press, Baltimore, Md.

Rosenthal, Y., P. Lam, E. A. Boyle, and J. Thomson (1995), Authigenic cadmium enrichments in suboxic sediments: Precipitation and postdepositional mobility, Earth Planet. Sci. Lett., 132, 99-111.

Shimmield, G. B., and T. F. Pedersen (1990), The geochemistry of reactive trace metals and halogens in hemipelagic continental margin sediments, Rev. Aquat. Sci., 3, 255-279.

Strickland, J. D. H., and T. R. Parsons (1972), Practical Handbook of Seawater Analysis, 311 pp., Fisheries. Res. Board of Can., Ottawa, Ont., Canada. 
Tada, R., S. Sato, T. Irino, H. Matsui, and J. P. Kennett (2000), Millennial-scale compositional variations in late Quaternary sediments at Site 1017, southern California, Proc. Ocean Drill. Program Sci. Results, 167, 277-296.

Takahashi, K. (1998), The Bering and Okhotsk seas: Modern and past paleoceanographic changes and gateway impact, J. Asian Earth Sci., $16,49-58$

Talley, L. D. (1991), An Okhotsk Sea water anomaly: Implications for ventilation in the North Pacific, Deep Sea Res., Part A, 38, S171-S190.

Thomson, J., N. C. Higgs, and S. Colley (1996), Diagenetic redistributions of redox-sensitive elements in northeast Atlantic glacial/interglacial transition sediments, Earth Planet. Sci. Lett., 139, 365-377.

Tisch, T. D., S. R. Ramp, and C. A. Collins (1992), Observations of the geostrophic current and water mass characteristics of Point Sur,
California, from May 1988 through November 1989, J. Geophys. Res., 97, 12,535-12,556.

van Geen, A., R. G. Fairbanks, P. Dartnell, M. McGann, J. V. Gardner, and M. Kashgarian (1996), Ventilation changes in the northeas Pacific during the last deglaciation, Paleoceanography, 11, 519-528.

Van Scoy, K. A., R. A. Fine, and H. G. Ostlund (1991a), Two decades of mixing tritium in the North Pacific Ocean, Deep Sea Res., Part A 38, S191-S219.

Van Scoy, K. A., D. B. Olson, and R. A. Fine (1991b), Ventilation of North Pacific Intermediate Waters: The role of the Alaskan Gyre, J. Geophys. Res., 96, 16,801-16,810.

Wong, G. T. F., K. Takayanagi, and J. F. Todd (1985), Dissolved Iodine in waters overlying and in the Orca Basin Gulf of Mexico, Mar: Chem., 17, 177-183.

Zheng, Y., R. F. Anderson, A. van Geen, and J. Kuwabara (2000a), Authigenic molybde- num formation in marine sediments: A link to pore water sulfide in the Santa Barbara Basin, Geochim. Cosmochim. Acta, 64, 4165-4178.

Zheng, Y., A. van Geen, R. F. Anderson, J. V. Gardner, and W. E. Dean (2000b), Intensification of the northeast Pacific oxygen minimum zone during the Bølling-Allerød warm period, Paleoceanography, 15, 528-536.

I. L. Hendy, Department of Geological Sciences, University of Michigan, 2534CC Little Building, 425 E. University Avenue, Ann Arbor, MI 48109, USA. (ihendy@umich. edu)

T. F. Pedersen, School of Earth and Ocean Sciences, University of Victoria, P.O. Box 3055 STN CSC, Victoria, B. C., Canada V8W 3P6. 